Fakultas komputer

Moh Tegar tri prakosa

Section 01

\title{
Algoritma dan Struktur data
}

\author{
Moh Tegar tri prakosa
}

195120050

Fakultas komputer

Moh.student@umitra.ac.id

\section{Algoritma}

definisi algoritma adalah sebuah susunan logis dan sistematis yang digunakan untuk memecahkan atau menyelesaikan suatu permasalahan tertentu. Meski begitu, jika dijabarkan lebih luas, terdapat beberapa arti algoritma yang disesuaikan dengan penggunaan bidangnya.

Awalnya kata algoritma atau algoritme muncul dari kata algoritmi ${ }^{6}$, bentuk latin dari AlKhwarizmi yang diambil dari nama Abu Abdullah Muhammad ibnu Musa Al-Khwarizmi, seorang matematikawan, ahli astronomi, dan ahli geografi dari Persia.

Dalam matematika dan ilmu komputer, algoritma adalah sebuah prosedur langkah-demilangkah untuk proses penghitungan. Algoritma digunakan untuk melakuakn penghitungan, pemrosesan data, dan penalaran otomatis sehingga bisa dilakukan dengan baik dan benar secara berurutan.Dimulai dari sebuah kondisi awal dan input awal (mungkin kosong), instruksi-instruksi tersebut menjelaskan sebuah komputasi yang, bila dieksekusi, diproses lewat sejumlah urutan 
kondisi terbatas yang terdefinisi dengan baik, yang pada akhirnya menghasilkan keluaran atau output dan berhenti di kondisi akhir.

\section{Input dan Output harus mempunyai batasan:}

input merupakan data yang dimasukkan

ke dalam algoritma yang untuk kemudian akan dilaksanakan oleh komputer. Dengan begitu, input yang diberikan harus sesuai dengan jenis dari bahasa pemrograman yang digunakan, sedangkan ouput merupakan hasil yang diperoleh dari pekerjaan yang dilaksanakan komputer untuk kepentingan user yang merupakan pihak diluar komputer. Algoritma harus menghasilkan output karena merupakan solusi yang

diharapkan dari suatu masalah yang timbul.

\section{STRUKTUR DATA}

Salah satu hal penting yang tidak dapat ditinggalkan dalam pemakaian komputer adalah data. Data dapat diperoleh dari berbagai sumber, misalkan hasil pengukuran laboratorium, hasil survei, hasil angket dan lain sebagainya. Komposisi data dan logika dari algoritma yang memanfaatkan data tersebut berhubungan sangat erat. Data sederhana dapat kita himpun ke dalam suatu struktur data yang memuat informasi tentang hubungan antara item yang terdapat di dalamnya.

\section{Pengertian Struktur Data}

Dalam istilah ilmu komputer, struktur data adalah cara penyimpanan, pengorganisasian, dan pengaturan data di dalam media penyimpanan komputer sehingga data tersebut dapat digunakan secara efisien.

Dalam teknik pemrograman, struktur data berarti tata letak data yang berisi kolom-kolom data,baik itu kolom yang tampak oleh pengguna (user) ataupunkolom yang hanya digunakan untuk keperluan pemrograman yang tidak tampak oleh pengguna. Setiap baris dari kumpulan kolom-kolom tersebut dinamakan catatan (record). Lebar kolom untuk data dapat berubah dan bervariasi. Ada kolom yang lebarnya berubah secara dinamis sesuai masukan dari pengguna dan juga ada kolom yang lebarnya tetap.

Dengan sifatnya ini, sebuah struktur data dapat diterapkan untuk pengolahan database, misalnya 
untuk keperluan data keuangan, atau untuk pengolah kata (word processor) yang kolomnya berubah secara dinamis. Contoh struktur data dapat dilihat pada file-file spreadsheet, database, pengolahan kata, gambar yang dikompres, dan pemampatan file (kompres) dengan teknik tertentu yang memanfaatkan struktur data.

\section{Klasifikasi Data}

Pada garis besarnya, data dapat dikategorikan menjadi:

A. Tipe Data Sederhana, yang terdiri dari:

- Data Sederhana Tunggal, misalnya Integer, Real, Boolean, dan Karakter.

- Data Sederhana Majemuk, misalnya String.

\section{B. Struktur Data}

- Struktur Data Sederhana, misalnya Array dan Record.

- Struktur Data majemuk, terdiri dari:

o Linier, misalnya: Stack, Queue, dan Linier Linked List.

o Nonlinier, misalnya Binary Tree, Binary Search Tree, Graph, dll.

Pemakaian struktur data yang tepat di dalam proses pemrograman akan menghasilkan algoritma yang lebih jelas dan tepat, sehingga menjadikan program secara keseluruhan lebih efisien dan sederhana. 


\section{A. PENDAHULUAN}

Materi Kuliah Membahas Tentang Pengertian Algoritma membahas mengenai Input dan Output, Contoh - contoh Bahasa Pemrograman Desction, dan Struktur Data

Adapun algoritma merupakan diskripsi pelaksanaan suatu proses dimana algoritma di susun oleh sederetan langkah langkah instruksi yang logis dan kata lain. Langkah langkah yang logis harus di laksanakan untuk memecahkan masalah.

Kata logismerupakan kata konci dalam sebiah algoritma langkah langkah di dalam algoritma harus logis ini berarti hasil dari urutan langkah langkah tersebut harus dapat di tentukan benar atau salah.langkah langkah yang tidak benar dapat memberikan hasil yang slah.

Sebagai contoh tinjau persoalan mempertukarkan isi 2 gelas,A dan B. Gelas A berisi air kopi sedangkan gelas B berisi air susu.kita ingin mempertukarkan isi kedua gelas itu sedemikian hingga gelas A.

Berisi Air Susu Dan Gelas B Berisi Aair Kopi Jika Kita Langsung Menungkan Air Kopi Yng Ada Di Gelas A Langsung K e Gelas B Maka Yang Didapatkan Adalah Gelas A Menjadi Kosong Dan Gelas B Menjadi Air Kopi Susu Begitu Juga Sebaliknya. Untuk Mempertukarkan Isi Dua Gelas Tersebut, Kita Memerlukan Sebuah Gelas Tambahan Yang Diperlukan Sebagai Tempat Penampungan Sementara Sebut Gelas Tambahan Tersebut Gelas C. Dengan Menggunakan Gelas Bantu C Ini Algoritma Mempertukarkan Isi Dua Buah Gelas Yang Benar Adalah Sebagai Berikut Ini : 
Algoritma dan Struktur Data 1

\author{
Mencari Luas Bujur Sangkar \\ Input Panjang Sisi \\ Luas Bujur Sangkar Adalah $\quad$ :...... \\ Tekan Enter Untuk Melanjutkan \\ Mencari Luas Segitiga Siku-Siku \\ Input Panjang Alas \\ :...... \\ Input Tinggi Segitiga \\ :...... \\ Luas Segitiga Adalah \\ :.......
}

Tekan Enter Untuk Melanjutkan

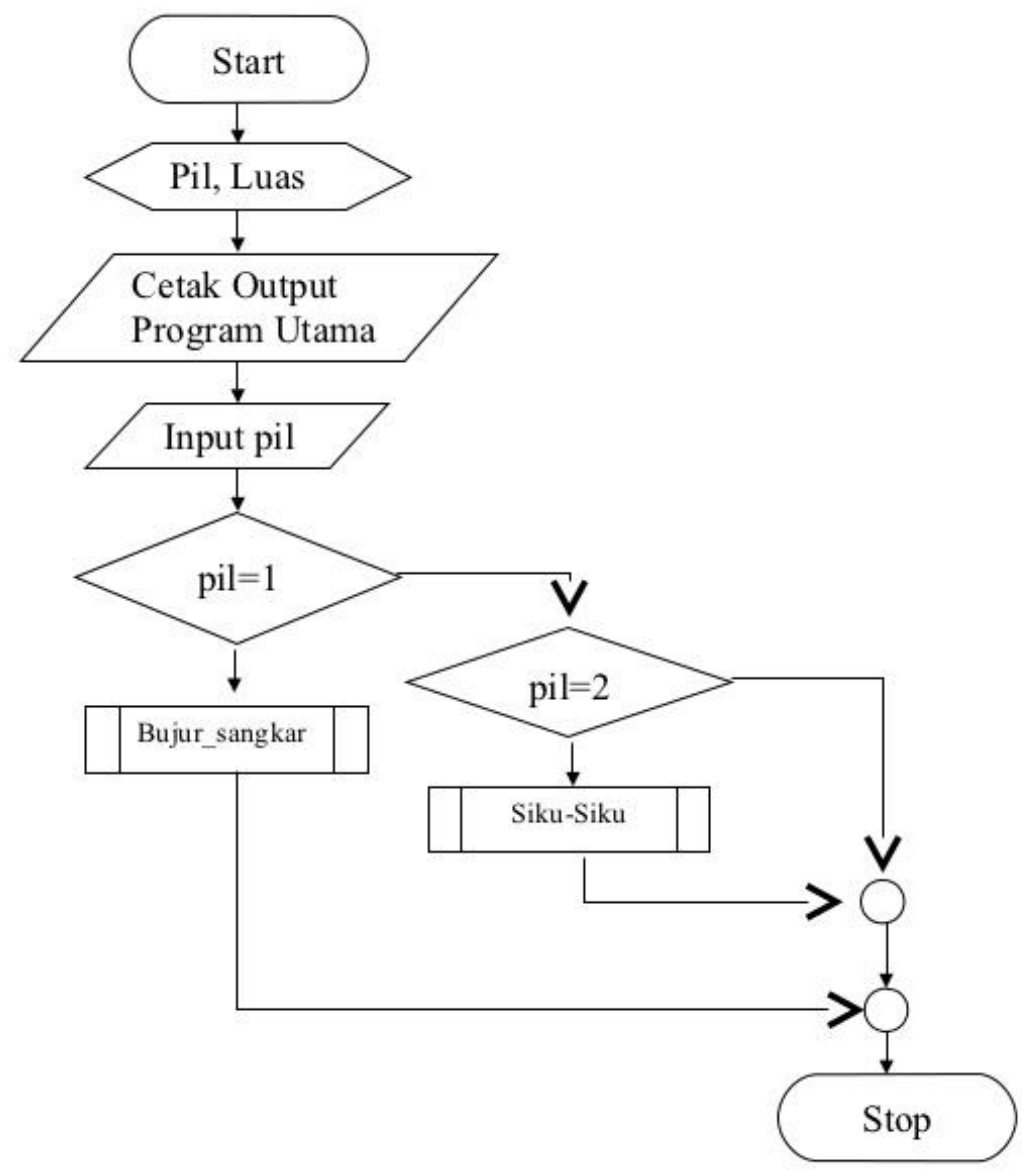

Team Dosen Algoritma dan Struktur Data 


\section{B. PEMBAHASAN / STUDI KASUS}

algoritma adalah sebuah susunan logis dan sistematis yang digunakan untuk memecahkan atau menyelesaikan suatu permasalahan tertentu. Meski begitu, jika dijabarkan lebih luas, terdapat beberapa arti algoritma yang disesuaikan dengan penggunaan bidangnya.

bentuk latin dari Al-Khwarizmi yang diambil dari nama Abu Abdullah Muhammad ibnu Musa Al-Khwarizmi, seorang matematikawan, ahli astronomi, dan ahli geografi dari Persia.

instruksi-instruksi tersebut menjelaskan sebuah komputasi yang, bila dieksekusi, diproses lewat sejumlah urutan kondisi terbatas yang terdefinisi dengan baik, yang pada akhirnya menghasilkan keluaran atau output dan berhenti di kondisi akhir.

\section{ID SECURITY}

\section{QWTD4452377-ASP-5244166}

\section{KESIMPULAN}

Algoritma adalah urutan aksi-aksi yang dinyatakan dengan jelas dan tidak rancu untuk memecahkan suatu masalah dalam rentang waktu tertentu. Setiap aksi harus dapat dikerjakan dan mempunyai efek tertentu. Algoritma merupakan logika, metode dan tahapan (urutan) sistematis yang digunakan untuk memecahkan suatu permasalahan. Algoritma dapat dituliskan dengan banyak cara, mulai dari menggunakan bahasa alami yang digunakan sehari-hari, simbol grafik bagan alir (flowchart), sampai menggunakan bahasa pemrograman seperti bahasa $\mathrm{C}$ atau $\mathrm{C}++$. 


\section{E. DISKUSI}

Saya Moh Tegar Tri Prakosa dan Bersama Temen Saya M. Rizq Daffa Jodi Kami Mendiskusikan tentang contoh ini dengan sangat baik hasil diskusi dari materi ini adalah Kami Berdua Membahas Materi Ini Yang Kami Diskusikan Pengertian Struktur Data Dan Pengertian algoritma Contoh Nya Gambar Flowchart Ciri-ciri Prinsip,Definisi,Dan kami Simpulkan Secara Ringkas

\section{F.REFERENCE}

[1] O. M. Febriani and A. S. Putra, "Sistem Informasi Monitoring Inventori Barang Pada Balai Riset Standardisasi Industri Bandar Lampung," J. Inform., vol. 13, no. 1, pp. 90-98, 2014.

[2] A. S. Putra, "Paperplain: Execution Fundamental Create Application With Borland Delphi 7.0 University Of Mitra Indonesia," 2018.

[3] A. S. Putra, "2018 Artikel Struktur Data, Audit Dan Jaringan Komputer," 2018.

[4] A. S. Putra, "AlIAS MANAGER USED IN DATABASE DESKTOP STUDI CASE DB DEMOS."

[5] A. S. Putra, "COMPREHENSIVE SET OF PROFESSIONAL FOR DISTRIBUTE COMPUTING."

[6] A. S. Putra, "DATA ORIENTED RECOGNITION IN BORLAND DELPHI 7.0."

[7] A. S. Putra, "EMBARCADERO DELPHI XE 2 IN GPU-POWERED FIREMONKEY APPLICATION."

[8] A. S. Putra, "HAK ATAS KEKAYAAN INTELEKTUAL DALAM DUNIA TEKNOLOGY BERBASIS REVOLUSI INDUSTRI 4.0."

[9] A. S. Putra, "IMPLEMENTASI PERATURAN PERUNDANGAN UU. NO 31 TAHUN 2000 TENTANG DESAIN INDUSTRI BERBASIS INFORMATION TECHNOLOGY."

[10] A. S. Putra, "IMPLEMENTATION OF PARADOX DBASE."

[11] A. S. Putra, "IMPLEMENTATION OF TRADE SECRET CASE STUDY SAMSUNG MOBILE PHONE."

[12] A. S. Putra, "IMPLEMENTATION PATENT FOR APPLICATION WEB BASED CASE STUDI WWW. PUBLIKLAMPUNG. COM."

[13] A. S. Putra, "IMPLEMENTATION SYSTEM FIRST TO INVENT IN DIGITALLY INDUSTRY."

[14] A. S. Putra, "MANUAL REPORT \& INTEGRATED DEVELOPMENT ENVIRONMENT BORLAND DELPHI 7.0." 
[15] A. S. Putra, "PATENT AS RELEVAN SUPPORT RESEARCH."

[16] A. S. Putra, "PATENT FOR RESEARCH STUdY CASE OF APPLE. Inc."

[17] A. S. Putra, "PATENT PROTECTION FOR APPLICATION INVENT."

[18] A. S. Putra, "QUICK REPORT IN PROPERTY PROGRAMMING."

[19] A. S. Putra, "REVIEW CIRCUIT LAYOUT COMPONENT REQUIREMENT ON ASUS NOTEBOOK."

[20] A. S. Putra, "REVIEW TRADEMARK PATENT FOR INDUSTRIAL TECHNOLOGY BASED 4.0."

[21] A. S. Putra, "TOOLBAR COMPONENT PALLETTE IN OBJECT ORIENTED PROGRAMMING."

[22] A. S. Putra, "WORKING DIRECTORY SET FOR PARADOX 7."

[23] A. S. Putra, "ZQUERY CONNECTION IMPLEMENTED PROGRAMMING STUDI CASE PT. BANK BCA Tbk."

[24] A. S. Putra, D. R. Aryanti, and I. Hartati, "Metode SAW (Simple Additive Weighting) sebagai Sistem Pendukung Keputusan Guru Berprestasi (Studi Kasus: SMK Global Surya)," in Prosiding Seminar Nasional Darmajaya, 2018, vol. 1, no. 1, pp. 85-97.

[25] A. S. Putra and O. M. Febriani, "Knowledge Management Online Application in PDAM Lampung Province," in Prosiding International conference on Information Technology and Business (ICITB), 2018, pp. 181-187.

[26] A. S. Putra, O. M. Febriani, and B. Bachry, "Implementasi Genetic Fuzzy System Untuk Mengidentifikasi Hasil Curian Kendaraan Bermotor Di Polda Lampung," SIMADA (Jurnal Sist. Inf. dan Manaj. Basis Data), vol. 1, no. 1, pp. 21-30, 2018.

[27] A. S. Putra, H. Sukri, and K. Zuhri, "Sistem Monitoring Realtime Jaringan Irigasi Desa (JIDES) Dengan Konsep Jaringan Sensor Nirkabel," IJEIS (Indonesian J. Electron. Instrum. Syst., vol. 8, no. 2, pp. 221-232.

[28] D. P. Sari, O. M. Febriani, and A. S. Putra, "Perancangan Sistem Informasi SDM Berprestasi pada SD Global Surya," in Prosiding Seminar Nasional Darmajaya, 2018, vol. 1, no. 1, pp. 289-294. 